\title{
Re-imagining Atomic Bombing and 9/11: Kamila Shamsie's Burnt Shadows
}

\author{
Gen'ichiro Itakura
}

Once he is in the cell they unshackle him and instruct him to strip. He takes off the grey winter coat with brisk efficiency and then - as they watch, arms folded - his movements slow, fear turning his fingers clumsy on belt buckle, shirt buttons.

They wait until he is completely naked before they gather up his clothes and leave. When he is dressed again, he suspects, he will be wearing an orange jumpsuit. ${ }^{1}$

Thus begins Kamila Shamsie's critically acclaimed 'post-9/11' novel, Burnt Shadows. This 'prologue' encapsulates the wide scope of the novel as well as its psychological and ethical depth. The unnamed male character's forced disrobing, as well as the orange jumpsuit, evokes the sexual humiliation undergone by prisoners of the Guantánamo Bay detention camp. Furthermore, the title of the novel, the reader soon learns, refers to the shadows burnt on Hiroko's back by the atomic bomb in Nagasaki on 9 August $1945 .{ }^{2}$ These two elements anticipate the novel's 'global' approach to the events that took place on 11 September 2001. The 'global' outlook of this novel sharply contrasts leading British and American novelists' responses that express 'the mélange of anger and anxiety' within the white population and unwittingly reveal their inability to extricate themselves from 'a kind of imaginative paralysis.' 3 On the other hand, the prologue does not provide any spatial or temporal specificity except for the deictic. This apparent lack reframes immediate socio-political concerns into more abstract, hypothetical questions of human ethics and psychology.

1 Ibid., 1.

2 Needless to say, Shamsie is not the first writer to relate the atomic bomb attacks on Hiroshima and Nagasaki to the events commonly known as ' $9 / 11$.' As the topos 'ground zero' was used to refer to the epicentres of the atomic bombs before 2001, the re-emergence of the term allegedly suggests the association of those two in America's popular imagination. See Gene Ray, Terror and the Sublime in Art and Critical Theory: From Auschwitz to September 11 and Beyond (London: Palgrave, 2005), 56.

3 Robert Eaglestone, 'The Age of Reason Is Over ... an Age of Fury Was Dawning,' Wasafiri 22.1 (2007), 19; Richard Gray, 'Open Doors, Closed Minds: American Prose Writing at a Time of Crisis,' American Literary History 21.1 (2009), 135.

(C) KONINKLIJKE BRILL NV, LEIDEN, 2019 | DOI:10.1163/9789004385931_004 
In this chapter, I would like to explore the ways Hiroko's struggles to work through the trauma are represented in relation to the novel's panoramic scope of modern history and geopolitics. Despite the novel's apparently 'postcolonial' or 'post-9/11' concerns - the residues of British colonialism, the rise of the mujahideen in Central Asia, the 'War on Terror'4 - it is the trauma Hiroko experiences in the atomic bomb attack, especially at the loss of her German fiancé, Konrad Weiss, that has a lasting impact on her life. First, I will identify the nature of the trauma suffered by Hiroko through analysis of the first part of the novel entitled 'The Yet Unknown World - Nagasaki, 9 August 1945,5 as well as numerous flashbacks to that day throughout the book. Hiroko's experience is also complicated by her subsequent losses: her Pakistani husband Sajjad Ashraf is shot by mistake; and her son Raza is arrested and most likely detained indefinitely. Then, I would like to trace her struggles to work through the trauma and move away from narcissistic preoccupations with her own suffering towards a more sensible consideration of suffering of the others. Through this shift, I argue, the novel helps the reader learn not only to 'mourn in global dimensions' but also to realise the 'precariousness of life.'

\section{$1 \quad$ Hiroko's Trauma}

Hiroko's traumatic experience of the atomic bomb in Nagasaki can be summed up as the experience of various forms of dehumanisation. Indeed, Shamsie's novel is founded on a certain kind of abstraction, or focus on such a concept, as opposed to the directness of the survivor narrative. It scarcely provides graphic details of victims, dead bodies and ruins after the attack. This lack sharply contrasts Japanese 'atomic-bomb' literature or the body of writing mainly by atomic bomb survivors, ranging from Tamiki Hara's frequently anthologised short story 'Natsu no Hana' ['Summer Flowers'] to Keiji Nakazawa's manga Hadashi no Gen [Barefoot Gen]. Hara's narrator is horrified at the sight of a 'herd of indescribably disfigured victims' ('gengo ni zessuru hitobito no mure') by the

4 For Shamsie's view of 'privileged' and 'unprevileged' migrancy, see Cara N. Cilano, Contemporary Pakistani Fiction in English: Idea, Nation, State (Abingdon, England: Routledge, 2013), 223-228. For the parallel between America's 'necropolitical logic' of the 'war on terror' and that of atomic warfare, see Stephen Morton, States of Emergency: Colonialism, Literature and Law (Liverpool: Liverpool University Press, 2013), 223. For an analysis of Shamsie's secularistliberal political stance, see Ruvani Ranasinha, 'Resistance and Religion in the Work of Kamila Shamsie,' Culture, Diaspora, and Modernity in Muslim Writing, ed. Rehana Ahmed, Peter Morey and Amina Yaqin (Abingdon: Routledge, 2012), 210-213.

5 Shamsie, Burnt Shadows, 4-30.

6 Butler, Precarious Life, 12. 
river, whilst Nakazawa's eight-year-old hero encounters a number of victims with heavy burns and melted skin. ${ }^{7}$ Shamsie apparently chooses not to follow the tradition of this atomic-bomb literature to re-imagine the impact of this traumatic event. ${ }^{8}$ Nor does she investigate the aftermaths of the bomb, notably the prevalence of acute radiation syndrome and radiation-related illnesses, the subsequent moral breakdown and the Atomic Bomb Casualty Commission's sheer disregard of the victims' human rights and dignity. By minimising the 'shock' factors, however, Shamsie foregrounds Hiroko's experience of trauma and its enduring impact. Nagasaki after the bomb is perceived as the landscape devoid of light or life, replete with debris, the 'sound of fire' and the 'smell of dead flesh. ${ }^{9}$ Later, Hiroko explains to Sajjad this dehumanising effect of the atomic bomb:

Those nearest the epicentre of the blast were eradicated completely, only the fat from their bodies sticking to the walls and rocks around them like shadows.... I looked for Konrad's shadow. I found it. Or I found something that I believed was it. On a rock. Such a lanky shadow. I sent a message to Yoshi Watanabe and together we rolled that rock to the International Cemetery ... She pressed a hand against her spine at the memory. And buried it. ${ }^{10}$

The contrast is obvious. The atomic bomb here instantaneously annihilates human lives, making the bodies disintegrate and evaporate. Their bodies bear no resemblance to humans or indeed to any living organism. Shamsie carefully avoids lyricism to recount the reduction of human bodies to 'shadows' an attempt reminiscent of Hara's typographical and/or orthographical experiments. ${ }^{11}$ In the meantime, Hiroko tries to restore the human from the

Tamiki Hara, 'Natsu no Hana,' Natsu no Hana, Shingan no Kuni [Summer Flowers, The Land of My Heart's Desire and Other Stories] (Tokyo:Shinchō-sha, 200o), 148; Keiji Nakazawa, Hadashi no Gen, vol. 1 (Tokyo: Chōbun-sha, 1975), 253-271; Nakazawa, Hadashi no Gen, vol. 2 (Tokyo: Chōbun-sha, 1975), 2-7, 15-18, 19, 32-46, 65-66, 68-69, 73-77, 83-84, 101-1-2, 108, 118. All English translations from Japanese are mine.

8 In fact, many Japanese writers have made the same choice as Shamsie, partly because the atomic bomb has been widely considered, like the Holocaust, the 'primal experience' that denies all but the survivors. John Whitter Treat, Writing Ground Zero:Japanese Literature and the Atomic Bomb (Chicago, IL: University of Chicago Press, 1995), 27.

9 Shamsie, Burnt Shadows, 27.

$10 \quad$ Ibid., 76-77; first ellipsis added.

11 Hara uses katakana to describe the absence of the 'human' and the presence of the 'odd' and 'mechanical' into which the atomic bomb reduces human bodies. Hara, 'Natsu no Hana,' 159, 158. Katakana, a Japanese syllabary mainly used to transliterate foreign words, 
dehumanised landscape. She finds a 'lanky' shadow on a rock and brings it to the cemetery to 'bury' it in place of Konrad's body. This contrast implicitly suggests Hiroko's horror is caused by this dehumanisation. This complete dematerialisation of human life recurs in a different context when Hiroko has a miscarriage two years later. Her daughter's presence has only been felt as 'a stirring within, a series of hiccups and kicks,' but nevertheless she is traumatised by the deprivation of life allegedly in an 'act of mercy.' ${ }^{\prime 2}$

Hiroko's horror at dehumanisation surfaces even after she becomes emotionally more mature. When her husband Sajjad Ashraf is shot dead, she is upset by his skin's 'coldness' and 'unyieldingness,' as well as the 'hardness' of his lifeless penis, and tries to find part of him that still feels 'alive.'13 The 'hardness' of his dead body contrasts the 'softness' while he was alive. When Hiroko remembers Konrad, she unconsciously seeks solace in resting her fingers on Sajjad's mouth and moustache. ${ }^{14}$ It is not merely lifelessness but transformation that horrifies her. In her effort not to traumatise children or to internalise her trauma, she makes up 'fairy tales' in place of more realistic accounts of her experience in Nagasaki. One of her 'fairy tales' unwittingly reveals the source of her horror:

There was the one about the girl whose dying father slithers towards her in the shape of a lizard; she is so horrified by his grotesqueness it takes her years to understand that his final act was to come towards her, after a lifetime of walking away. ${ }^{15}$

Hiroko sees her father, severely injured and deformed, 'slither' towards her. ${ }^{16}$ The iconicity of images of crawling human figures, commonly found in Japanese 'atomic bomb' literature and photographs, encapsulates the horror of dehumanisation. This iconicity appears precisely where an individual victimwriter's personal experience of trauma merges with certain 'ahistoricity' of some of masterpieces of atomic-bomb literature. As John Whitter Treat argues,

notably technical terms and scientific jargon, is rarely if at all used to express emotions, except for ones of non-humans such as ghosts and artificial intelligence.

Shamsie, Burnt Shadows, 205. Worthwhile noting, although totally different in reality, Hiroko feels this medical 'mercy killing' as traumatising as the atomic bomb, an industrialised genocide, considered less cruel in America's necropolitical discourse. Ray, Terror and the Sublime in Art and Critical Theory, 102.

13 Shamsie, Burnt Shadows, 240.

14 Ibid., 205.

15 Ibid., 177.

16 Ibid., 27. 
the tragedy of the atomic bombings that has thrust the victims into 'unknown and meaningless suffering' can only be intelligible or recognised as a tragedy by making it knowable - in other words, ahistoricising it. ${ }^{17}$ Hiroko's 'fairy tale' evokes the same kind of ahistoricity by inciting primeval horror as Gen's first reaction - 'Min'na obake daaa!' ['Oh no, everyone here's a monster!'] - to heavily disfigured victims in Hadashi no Gen. ${ }^{18}$ Hiroko's 'fairy tale' is not merely predicated upon her real experience but also upon a more deep-seated, primeval horror of humans turning into something else or shape-shifting shared not only by the survivors of the atomic bombing but also by many people across cultures, given the prevalence of folktales of horrifying shape-shifters.

Significantly, the atomic bomb provides a threat to her autonomy as an individual, as a human. Indeed, the burns on the back can be read as trauma inscribed on her body. Hiroko's stigma invariably functions as a reminder of her experience of the atomic bomb and her horror at the sheer dehumanisation it brings to her hometown. However, her scars also represent death in life, the inanimate in the animate.

She glides her hand over her shoulder, touches flesh where there should be silk. Moves her hand further down her back, touches what is neither flesh nor silk but both. She wonders if this has something to do with the burning she felt as she fell. Now there is no feeling. She taps the place that is neither flesh nor silk. There is no feeling at all. ${ }^{19}$

The burns here are perceived as 'neither flesh nor silk,' neither human nor artificial, neither animate nor inanimate. In fact, it is not usually the melting of the garments but the intense flash of the atomic bomb that causes burns on the skin covered by the dark portions of the garments. Furthermore, this ambiguous condition of burns does not typically haunt a victim in Japanese atomic-bomb literature. Keloidal scars stigmatise protagonists in reality and fiction, notably in Minoru Betsuyaku's famous play Zō [The Elephant], whereas

\footnotetext{
17 Treat, Writing Ground Zero, 64.

18 Nakazawa, Hadashi no Gen, vol. 1, 254. However, such description is often accompanied by the protagonist's sense of guilt or shame, rarely found in Western literature of atomic bombs. Kyōko Hayashi's short story 'Akikan' ('The Empty Tin') centres on this theme, whilst Fumiyo Kōno's manga Yūnagi no Machi [The City of Evening Calm] provides an excellent example of visualisation of the heroine's sense of guilt. See Kōno, Yūnagi no Machi, Sakura no Kuni [The City of Evening Calm and The Country of Cherry Blossoms] (Tokyo: Futaba-sha, 2004), 23-24.

19 Shamsie, Burnt Shadows, 26.
} 
not only haemoptysis and diarrhoea but also alopecia or the loss of hair which frequently appears in Hadashi no Gen - signals the onset of fatal radiation-related illnesses. Despite these oddities, however, Shamsie adds thematic depth to these literally skin-deep, stylised scars. Hiroko perceives her injury as the process that dehumanises - at least in part - her body, literally and symbolically.

Her finger can feel her back but her back cannot feel her fingers. Charred silk, seared flesh. How is this possible? Urakami Valley has become her flesh. Her flesh has become Urakami Valley. She runs her thumb over what was once skin. It is bumped and raw, lifeless. ${ }^{20}$

Her burns are now linked to the modern history of the Urakami Valley area, as they continue to function as a reminder of the atomic bombing of Nagasaki. This symbolic meaning does not eclipse the importance of the lifelessness of her skin. She is eternally bound up with the Urakami Valley of August 1945 or what it stands for: devastation and dehumanisation by an atomic bomb. Given the immensity of this historical event, Hiroko fears being subordinated to this temporality and locality and thereby deprived of anything irrelevant to the atomic bomb.

This horror also accounts for Hiroko's resistance to the labelling of 'hibakusha' or the atomic bomb victim, ${ }^{21}$ not often explored explicitly in Japanese atomic-bomb literature but nevertheless offering insight into the victims' psychological trauma. Hiroko explains to Elizabeth:

I don't want to hide these burns on my back, but I don't want people to judge me by them either. Hibakusha. I hate that word. It reduces you to the bomb. Every atom of you. ${ }^{22}$

Importantly, she does not describe the social exclusion or segregation of hibakusha in such words as 'prejudices' or 'discrimination' as many Japanese would do. Both Betsuyaku's $Z \bar{o}$ and Kyōko Hayashi's short story 'Matsuri no Ba' ['The Festive Place'] explore various forms of discrimination against hibakusha, especially the type of discrimination from which the victims suffer all the more intensely for the postwar government's legislation to 'save' hibakusha on an

\footnotetext{
20 Ibid., 27.

21 In Japanese, the word hibakusha literally means a person killed or wounded in a bomb attack, notably an atomic bomb attack. It is also used to describe a person exposed to hazardous radioactive substances after the bomb. 
admittedly superficial level. Instead, Hiroko draws our attention to the dehumanising aspect of this stigmatisation. She does not fear the exposure of her own 'deformity' or the grotesqueness of her back to the scrutinising gaze of the public. Rather, she is terrified of being 'reduced' to 'the bomb.' The use of the label hibakusha no longer defines her individuality and her identity but her having survived a bomb attack. Her decision to leave Japan stems not so much from her desire to escape from humiliation and persecution as her repulsion for such dehumanisation. Interestingly, her son Raza encounters prejudices against hibakusha and their children in India, but in a way different from Japanese narratives of hibakusha mostly set in Japan. Salma, Raza's then girlfriend, explains to him on the phone why her parents do not allow her to marry him an episode reminiscent of Kiyomi Hotta's play Shima [The Island]:

Nagasaki. The bomb. No one will give their daughter to you in marriage unless they're desperate, Raza. You could be deformed.... You might have something you can pass on to your children. I've seen the pictures. Of babies born in Nagasaki after the bomb.... This is how people think about you. ${ }^{23}$

It is not so much visible signs of hibakusha like keloids or alopecia as being born to a hibakusha's family that arouses or intensifies fear and prejudices against them. Salma's choice of imprecise words ('deformed' and 'something') reveals her own - and her parents' - lack of knowledge or first-hand experience of witnessing the victims' suffering. In other words, this ignorance reduces Raza to the name of his mother's birthplace or what it stands for: the atomic bomb. Looked at with this hindsight, Hotta's Shima examines a similar kind of dehumanisation through the labelling. Like Raza, Hotta's hero Manabu Kurihara is forced to give up his beloved, Reiko Kido, who loves him more faithfully and passionately than Salma loves Raza. Although a hibakusha with burns on the back and with a birthplace - Hiroshima, in his case - whose name does not incite an acute fear among the Kido family, Manabu is 'reduced to the atomic bomb' in a highly similar way: he is banished into the realm of the living dead, all those people deprived of their individuality, let alone free will. His last words, 'Kuso, ikite miseruzo' ['I must survive by all means'], are often interpreted as his will to challenge his own tragic fate, but it can also read as his resistance to this particular type of dehumanisation. ${ }^{24}$ In this - perhaps

23 Ibid., 189; ellipses added.

24 Kiyomi Hotta,Shima,NihonnoGenbakuBungaku[JapaneseAtomic-BombLiterature], vol.12, ed. Kenzaburo Oe et al., (Tokyo: Horupu, 1983), 83 . 
unconventional - way, Hiroko's resistance sheds light on a hitherto unexplored aspect of hibakusha's suffering or psychological trauma.

\section{$2 \quad$ Hiroko's Mourning}

Burnt Shadows does not merely provide a psychological study of its protagonist's personal trauma; rather, it adds an ethical dimension to this trauma. This ethical theme develops in two stages. First, Shamsie traces the ways Hiroko comes to terms with her personal trauma and manages to move on to a higher ethical stage. At the outset, she consciously tries to repress the trauma and negate her past, even though she belongs to positive thinkers or, to use her own words, 'those who could step out from loss.' ${ }^{25}$ Then, she goes through a series of ordeals to attain a certain level of moral maturity. Secondly, Shamsie implicitly suggests that the readers should recapitulate Hiroko's moral development until they finally acquire the ability to mourn in global dimensions, rather than remain mired in the melancholia. This development can compare with Freud's analysis of 'melancholia' in relation to 'mourning.' According to Freud, melancholia is accompanied by an 'extraordinary diminution in [one's] self-regard, an impoverishment of [one's] ego on a grand scale' that makes the patient to expect to be punished, whilst mourning is a self-controlled action. ${ }^{26}$ By showing that Hiroko clearly steps out of this melancholia, Shamsie invites the reader to participate in a more meaningful act of mourning.

Indeed, Hiroko translates her personal sorrow into a more universal ethical theme. Fifty-six years after the attack, she tries to relativise her experience by reading books and manages to suppress her personal sorrow and anger at the atomic bomb. She confesses her doubt about the importance of the event to Kim.

My stories seemed so small, so tiny a fragment in the big picture. Even Nagasaki - seventy-five thousand dead; it's just a fraction of the seventytwo million who died in the war. A tiny fraction. Just over .oo1 per cent. Why all this fuss about .oo1 per cent? ${ }^{27}$

25 Shamsie, Burnt Shadows, 146.

26 Sigmund Freud, 'Mourning and Melancholia,' On the History of the Psychoanalytic Movement, Papers and Metapsychology and Other Works, ed. and tr. James Strachey (London: Vintage, 2001), 245-246.

27 Shamsie, Burnt Shadows, 293. 75,000 is a strangely underestimated number. According to Nagasaki City's official record, 162,083 people died because of the atomic bomb attack and radiation-related illnesses. 
By this questioning, she clearly does not endorse - or expect Kim to endorse an American myth of Hiroshima and Nagasaki according to which the annihilation of the two cities and 330,000 lives was a 'necessary' action. Nor does she expect such a personal comment as Kim's, a comment that no matter how small the number may be, the bombing of Nagasaki is important for her because she experienced it. Rather, Hiroko strenuously strives to consider her personal loss, her personal tragedy in a broader context, making it into an ethical question. She becomes less and less personal towards the end.

You just have to put them in a little corner of the big picture. In the big picture of the Second World War, what was seventy-five thousand more Japanese dead? Acceptable, that's what it was. In the big picture of threats to America, what is one Afghan? Expendable. Maybe he's guilty, maybe not. Why risk it? ... But right now, because of you, I understand for the first time how nations can applaud when their government drop a second nuclear bomb. ${ }^{28}$

Interestingly, Hiroko somehow channels her personal sorrow and anger at various events culminating in her son's arrest into a more extensive consideration of moral justice and acceptability of disregarding suffering in the others. She discovers the same structure of feelings in the American myth of Hiroshima and Nagasaki and in the popular narrative of the War on Terror: Japanese or Muslim lives are not conceived of as lives in the 'big picture' that always puts US citizens at the centre. Like Judith Butler, Hiroko condemns that which has 'foreclosed' our 'ability to mourn in global dimensions.'29

Hiroko does not so much predicate her indictment of Americans upon her political position as her sense of morality. After her remark, Hiroko and Kim lapse into an awkward silence.

The silence that followed was the silence of intimates who find themselves strangers. The dark birds were between them, their burnt feathers everywhere. ${ }^{30}$

The bird-shaped burns on her back used to act as a mere reminder of her past trauma; but they now function as a guarantor of difference - the difference between those who can understand other people's suffering and mourn their lives and those who cannot. Like these burns, her trauma is inscribed in

28 Ibid., 362; ellipsis added.

29 Butler, Precarious Life, 12.

30 Shamsie, Burnt Shadows, 362. 
her body. Now the burns begin to connote her ability to suffer and mourn for other people, as if their suffering were felt like her own burns. According to Emmanuel Levinas, such a realisation of other people's sufferings opens an ethical perspective. ${ }^{31}$

Dans cette perspective se fait une différence radicale entre la souffrance en autrui où elle est, pour moi impardonnable et me sollicite et m'appelle, et la souffrance en moi, ma propre aventure de la souffrance dont l'inutilité constitutionnelle et congénitale peut prendre un sens, le seul dont la souffrance soit susceptible, en devenant une souffrance pour la souffrance, fût-elle inexorable, de quelqu'un d'autre. ${ }^{32}$

In this perspective there is a radical difference between the suffering in the other, where it is unforgivable to me, solicits me and calls me, and suffering in me, my own experience of suffering, whose constitutional or congenital uselessness can take on a meaning, the only one of which suffering is capable, in becoming a suffering for the suffering (inexorable though it may be) of someone else. ${ }^{33}$

Suffering in the Other (souffrance en autrui) is quintessentially meaningless. So is suffering in oneself (souffrance en moi), as long as only experienced as unbearable pain it inflicts upon an individual. Suffering in oneself makes sense and opens up a new ethical perspective on interpersonal relationship only when it becomes suffering for suffering in the Other (souffrance pour la souffrance de quelqu'un d'autre) - that is the only ethical sense that, according to Levinas, suffering in oneself can make. This ethical turn appears in Hiroko's 'dark birds' or 'burnt shadows.' They do not have any ethical meaning as long as they remain her personal trauma, suffering in oneself. They open up a new ethical horizon only when they appear as suffering in the Other. Her final remark thus represents not merely her righteous indignation against America's neo-imperialism but also her move towards a higher, more advanced stage of interpersonal ethics.

This ethical turn affects our reading of this novel, especially its prologue. The unnamed guards 'instruct' Raza to take off his clothes and 'wait.' They do

31 Emmanuel Levinas, Entre Nous: Essais sur le penser-à-l'autre (Paris: Grasset, 1991): 110-111; Entre Nous: Thinking-of-the-Other, tr. Michael B. Smith and Barbara Harshav (New York: Continuum, 2006): 80-81. 
'watch' him, but just to check if he finishes undressing himself, proving totally devoid of compassion or interest in what he is thinking of or how he must be feeling. ${ }^{34}$ They are not only 'faceless' but also indifferent to other people's faces. In Levinas' interpersonal ethics, the irreducible otherness of the face engenders our moral imperative, 'thou shall not kill,' which has ethical implications far beyond its Judeo-Christian theological roots. ${ }^{35}$

Le lien avec autrui ne se noue que comme responsabilité, que celleci, d'ailleurs, soit acceptée ou refusée, que l'on sache ou non comment l'assumer, que l'on puisse ou non faire quelque chose de concret pour autrui. Dire : me voici. Faire quelque chose pour un autre. Donner. Etre esprit humain, c'est cela. L'incarnation de la subjectivité humaine garantit sa spiritualité ... Dia-conie avant tout dialogue : j'analyse la relation inter-humaine comme si, dans la proximité avec autrui ... son visage, expressif en autrui (en tout le corps humain est, en ce sens, plus ou moins, le visage), était ce qui m'ordonne de le servir. ${ }^{36}$

The tie with the Other is knotted only as responsibility, this moreover, whether accepted or refused, whether knowing or not knowing how to assume it, whether able or unable to do something concrete for the Other. To say: here I am [ me voici]. To do something for the Other. To give. To be human spirit, that's it.... Dia-chrony [sic.] before all dialogue: I analyze the inter-human relationship as if, in proximity with the Other ... his face, the expressive in the Other (and the whole human body is in this sense more or less face), were what ordains me to serve him. ${ }^{37}$

All ethically meaningful interpersonal relationships are founded upon the sense of responsibility, with dialogue preceded by 'dia-conia' (dia-conie), read here as the act of serving or the readiness to serve the Other as apparent in the biblical phrase 'me voici. ${ }^{38}$ Such interpersonal relationships cannot be

\footnotetext{
34 Shamsie, Burnt Shadows, 1.

35 Emmanuel Levinas, Étique et infini: Dialogues avec Philippe Nemo (Paris: Fayard, 1982): 81; Ethics and Infinity: Conversation with Philippe Nemo, tr. Richard A. Cohen (Pittsburgh, PA: Duquesne University Press, 1985), 87.

36 Levinas, Étique et infini, 93-94; ellipses added.

37 Levinas, Ethics and Infinity, 97; ellipses added. The word 'dia-chrony' in Richard A. Cohen's English translation should read 'dia-conia.'

38 'Me voici,' translated as 'Here I am' or 'Here am I,' is the words that appear frequently in the Old Testament, most notably in Genesis 22:1 where Abraham uses the phrase to show God his readiness to serve Him.
} 
established without recognition of the 'face' or irreducible individuality. Neither 'dia-conia' nor 'dialogue' takes place in the prologue of the novel, where the unnamed guards order the unnamed prisoner to take off his clothes and see him do it. The absence of interpersonal relationship between them is confirmed by the guards' indifference to the unnamed prisoner's - most likely Raza's - face. Nothing in him arouses any sympathy, let alone 'ordains' them 'to serve him.' Suffering in him remains truly inutile in the commonest meaning of the word. This paradoxically contrasts the difference between their total apathy and the reader's ability to see the 'face,' understand its signification, and translate it into their own action.

Hiroko's mourning in Burnt Shadows links the atomic bombing of Nagasaki to $9 / 11$ in a way that makes it possible to restore the ability to 'mourn in global dimensions,' to borrow Judith Butler's words. ${ }^{39}$ Butler uses this phrase to illuminate - and then criticise - the de facto prohibition of mourning for people of certain ethnic origins or religious backgrounds or excessive emphasis on narcissistic melancholia in post-9/11 America and, by extension, its allies in 'War on Terror.' Considering our act of grieving and its political uses, she proposes a possibility of channelling grieving in better directions:

But this can be a point of departure for a new understanding if the narcissistic preoccupation of melancholia can be moved into a consideration of the vulnerability of others. Then we might critically evaluate and oppose the conditions under which certain human lives are more vulnerable than the others, and thus certain human lives are more grievable than others. From where might a principle emerge by which we vow to protect others from the kinds of violence we have suffered, if not from an apprehension of a common human vulnerability? ${ }^{40}$

According to Butler, our ethical sense of responsibility is founded upon our consideration of 'the vulnerability of others,' which includes Levinas' suffering for suffering in the Other (souffrance pour la souffrance quelqu'un d'autre). She translates this ethical consideration into a debate on the politics or political implications of our grieving and mourning. Burnt Shadows also opens a new

39 Butler, Precarious Life, 12.

40 Ibid., 30. 
perspective on mourning in the post-9/11 globalised world or introduces a new context in which to discuss this issue.

Unlike Jonathan Safran Foer's Extremely Loud and Incredibly Close, Burnt Shadows explores the themes of loss from people marginalised in the dominant discourse of the West. In Foer's novel, 'Mohammed Atta' is cited as an 'evil,' abhorrent figure who Oskar Schell believes stands in stark contrast to his 'good' father, though no Muslim characters appear in this book..$^{41}$ Oskar plays a recorded interview of Tomoyasu, a survivor of the atomic bombing of Hiroshima, on his portable cassette player. ${ }^{42}$ Foer chooses not to explore this subject further or give as much importance to Tomoyasu's story as he does to those of victims of the Dresden bombing and the 9/11 terrorist attacks. Underprivileged and/or underrepresented ethnic minorities such as young American Muslims and non-Japanese victims of the atomic bomb are naturally excluded from the landscape of Extremely Loud and Incredibly Close. ${ }^{43}$ This absence, according to Butler, has foreclosed our ability to 'mourn in global dimensions.' Also, it is precisely this void that Burnt Shadows tries to fill by shedding light on and familiarising hitherto underrepresented groups of people. The novel requests from the reader to extend their sympathy by encouraging a better understanding of sufferings and concerns affecting people from diverse backgrounds at different times in history.

Significantly, Hiroko's view of two 'grounds zero' forges a link between the two events rarely if at all discussed together and thereby provides a new perspective for contemporary readers in English-speaking countries, a large majority of whom allegedly reluctant to extend their sympathy to victims of one of the incidents. Hiroko compares the ground zero of New York to that of Nagasaki as if the latter were more familiar than the former. Needless to say, the atomic bombing of Nagasaki took place earlier in history and opens the first chapter of Burnt Shadows, which helps increase the reader's familiarity to the event. Nevertheless, Anglophone readers, a majority of whom are from former Allies of World War II, are more likely exposed to an American myth of the atomic bombings as necessary actions, arguably rooted in and endorsed by the 'long tradition of American moral exceptionalism' and the 'promise of the Enlightenment tradition. ${ }^{44}$ According to this myth, the United States is qualified

41 Jonathan Safran Foer, Extremely Loud and Incredibly Close (London: Hamilton, 2005), 159.

42 Ibid., 187-189.

43 That may not apply to Japanese atomic-bomb literature, as it often provides an appropriately multiethnic, multicultural landscape with Koreans and Western prisoners-of-war. Even manga like Hadashi no Gen has episodes of an American victim and a Korean family. Nakazawa, Hadashi no Gen, vol. 2, 36-37, 177-192.

Ray, Terror and the Sublime in Art and Critical Theory, 102. 
to employ 'mass terror' such as nuclear bombings to what its nation considers 'just causes' and thereby 'enlighten' a non-European nation. Needless to say, there has been a well-founded counter-argument: the nuclear means may well be 'judged disproportionate and counterproductive to the end of a free and perpetual peace;' furthermore, it 'globalizes the threat of instantaneous extermination. ${ }^{45}$ According to some, an 'institutionalized racism' can be detected behind the decision of the Truman administration to execute mass killings. ${ }^{46}$ When Hiroko sees a photo of a young New Yorker with the words 'MISSING SINCE 9/11' and 'IF ANY INFORMATION ABOUT LUIS RIVERA PLEASE CALL ..., ' the memory of Nagasaki temporarily overwhelms her:

Hiroko thought of the train station at Nagasaki, the day Yoshi had taken her to Tokyo. The walls plastered with signs asking for news of missing people. She stepped closer to take in the smile of Luis Rivera, its unfettered optimism. In moments such as these it seemed entirely wrong to feel oneself living in a different history to the people of this city. ${ }^{47}$

Pictures with notes pasted on the wall constitute one of the iconic images of 9/11 circulated in the globalised Western news media, but the image of Luis Rivera here does not simply refer the reader to this already familiar narrative of post-9/11 melancholia. It also helps the reader reimagine the bombing of Nagasaki so that they can fully understand the suffering of victims as well as the terror effect of the atomic bomb on Nagasaki on Japanese people - the number of casualties during the bombing of Nagasaki alone rises 50 times above the total casualties of the $9 / 11$ multiple attacks - and a strong reaction or hatred it might have incited. By de-familiarising 9/11, Shamsie provides a context in which to understand the two events in global dimensions.

Interestingly, Hiroko suddenly recalls Nagasaki when seeing a beautiful photograph of Afghanistan, one of the countries most frequently demonised or at least dismissed as creatures 'outside the "human"' in the Western media. ${ }^{48}$ Abdullah shows her a photo of Kandahar before the wars and points out to her that since it was taken the trees have been cut down, landmines have been planted and cluster bombs have been scattered. ${ }^{49}$ That somehow brings back memories to her:

\footnotetext{
45 Ibid., 102.

46 Ibid., 102.

47 Shamsie, Burnt Shadows, 274.

48 Butler, Precarious Life, 32.

49 Shamsie, Burnt Shadows, 309-310.
} 
Hiroko nodded, touching the page as reverently as Abdullah had. It was difficult to find photographs of Nagasaki that preceded the bomb, but Kim had presented her with what remained in the Burton family of George Burton's old pictures - Azalea Manor, the bund, Megane-Bashi when the river was high - and when she looked at them she was surprised by how strong a grip childhood had on her ageing mind. ${ }^{50}$

Not even 'a ground zero,' Kandahar has taken an apparently different course of history. The reader cannot decipher whether Hiroko fully sympathises with Abdullah or understands his frustration and rage. Despite these, however, the above quotation calls to mind the possibility that the gap between the two two individuals, two cities, two histories - can be filled by such respectfulness to the others as Hiroko's 'reverence,' accompanied by an effort to find a link between oneself and the Other, not by complete identification with the Other.

Such reverence helps develop the ethical question of the novel: channelling trauma to an ethical action. Indeed, the scope of the novel goes far beyond a simple act of accommodating people formerly excluded in the Western media. Hiroko does not efface herself - or rather strip herself of her memories and cultural baggage - to identify fully with Abdullah, who ends up drawn to an Islamist ideology. She does not simply indulge in her reminiscences about her past, either. She remains respectful of Abdullah. Their coexistence can read as a critique of the post-9/11 intellectual climate that understands everything in a clear-cut dichotomy of good and evil, just and unjust and that bans critical discourse, as shown in Rodolph Giuliani's response to Alwaleed bin Talal's remark. ${ }^{51}$ Shamsie does not duplicate this black-and-white worldview, nor does she turn it upside down. Instead, Hiroko's respectfulness can read as a critique of intolerance, as it allows those considered non-existent to assume a certain level of reality. ${ }^{52}$ Her willingness to participate or 'serve' opens a meaningful interaction.

Abdullah continued to turn the pages of the book, stopping briefly on some pictures, lingering over others. Occasionally he'd point out a detail to Hiroko - a goat rearing on its hind legs in the corner of one photograph with the poise of a dancer, a kite flying high above a dome painted an identical green which made the kite appear an escaping roof tile.

$50 \quad$ Ibid., 311.

$5^{1}$ Butler, Precarious Life, 12.

$5^{2}$ Butler argues that an inclusion of the excluded does not constitute a valid critique; rather, ontological questioning of reality does. Ibid., 33 . 
Sometimes he'd point to an object and identify it in Pashto - she'd repeat the word, pleased when she found any overlap with Urdu and delighted when she found resemblance to the Hindko words she had learnt while in Abbottabad. ${ }^{53}$

The image of a man and a woman reading the same book here implies a certain level of intimacy - almost sexual, despite Hiroko's age in this part of the novel an interpretation endorsed by the references to the pleasure she feels. Despite their difference, they manage to forge a rapport, albeit temporary, to the extent where they feel comfortable with each other's presence. Hiroko's sitting with Abdullah can be compared to Levinas' conception of the interpersonal relationship or 'true togetherness,' the first step towards the escape from a solitary being, as a 'togetherness of face-to-face' ('ensemble de face à face'), not a 'togetherness of synthesis' ('ensemble de synthèse'). ${ }^{54}$ Hiroko treats Abdullah with due respect as a human being. In this sense, Hiroko manages to find a way to deal with the Other - which can be seen as an ethical action on her part.

\section{Conclusion}

In Burnt Shadows, Shamsie translates the protagonist's trauma into a more ethically meaningful act, a personal experience of horror into a responsible action. Like many literary works on the atomic bombs, it indicts dehumanising aspects of the bomb, though in a less graphic manner. Konrad's transformation into a shadow on a rock, as well as her father's metamorphosis into a lizard, encapsulates the kind of dehumanisation the novel condemns. It conjures a primordial horror of shape-shifting and the blurring of boundaries between the animate and the inanimate - or life and death - and the total annihilation of life. The experience of trauma such as Hiroko's also appears in post-9/11 literature. In Foer's Extremely Loud and Incredibly Close, the empty coffin of the young protagonist's father signifies this sort of annihilation and therefore produces a traumatic effect on the son. ${ }^{55}$ Interestingly, Hiroko does not merely channel her trauma into an ethical question - how she should 'mourn' the loss in the 'big picture' of world history - but suggests that this ethical question deserves lifelong pursuit.

53 Shamsie, Burnt Shadows, 311.

54 Levinas, Éthique et infini, 72; Ethics and Infinity, 77.

55 Foer, Extremely Loud and Incredibly Close, 36, cf. 172-173. 
Indeed, Shamsie manages to add a new dimension to atomic bomb literature as well as post-9/11 literature by turning the trauma into an ethical theme. Towards the end of the novel, Hiroko's burns take on another meaning - the one other than her personal trauma - namely her own suffering experienced as suffering in the Other. This ethical turn can read as an attempt to reintegrate the traumatised self rather than recapitulate the melancholia or 'acting out.'56 In this respect, not only does the novel interrogate the widely-held narratives of Hiroshima/Nagasaki and 9/11 but with this ethical turn it also helps broaden the scope of literary representation of trauma.

\section{Bibliography}

Butler, Judith. Precarious Life: The Powers of Mourning and Violence. London: Verso, 2004.

Cilano, Cara N. Contemporary Pakistani Fiction in English:Idea, Nation, State. Abingdon, England: Routledge, 2013.

Eaglestone, Robert. 'The Age of Reason Is Over ... an Age of Fury Was Dawning.' Wasafiri 22.2 (2007): 19-22.

Foer, Jonathan Safran. Extremely Loud and Incredibly Close. London: Hamilton, 2005.

Freud, Sigmund. 'Mourning and Melancholia.' In On the History of the Psychoanalytic Movement, Papers and Metapsychology and Other Works. Edited by James Strachey, 237-26o. Translated by James Strachey. London: Vintage, 2001.

Gray, Richard. 'Open Doors, Closed Minds: American Prose Writing at a Time of Crisis.' American Literary History 21.1 (2009): 128-251.

Hara, Tamiki. 'Natsu no Hana.' ['Summer Flowers.'] Natsu no Hana, Shingan no Kuni. [Summer Flowers, The Land of My Heart's Desire and Other Stories.] Tokyo: Shinchōsha, 2000. 140-162.

Hayashi,Kyōko.'Akikan.'['TheEmptyTin.'] GiyamanBiidro.[CutGlass.]Tokyo:Kōdan-sha, 1978. 7-26.

Hotta, Kiyomi. Shima. [The Island.] In Nihon no Genbaku Bungaku. [Japanese 'AtomicBomb' Literature.] Edited by Kenzaburo Oe et al., 9-83. Tokyo: Horupu, 1983.

Kōno, Fumiyo. Yünagi no Machi, Sakura no Kuni. [The City of Evening Calm and The Country of Cherry Blossoms.] Tokyo: Futaba-sha, 2004.

Levinas, Emmanuel. Entre Nous: Essais sur le penser-à-l'autre. Paris: Grasset, 1991.

$5^{6}$ For Levinas' discussion of psychosis and ethics or a sense of responsibility, see Emmanuel Levinas, Otherwise than Being or Beyond Essence, tr. Alphonso Lingis (Pittsburgh, PA: Duquesne University Press, 2011): 142. 
Levinas, Emmanuel. Entre Nous: Thinking-of-the-Other. Translated by Michael B. Smith and Barbara Harshav. New York: Continuum, 2006.

Levinas, Emmanuel. Ethics and Infinity: Conversations with Philippe Nemo. Translated by Richard A. Cohen. Pittsburgh, PA: Duquesne University Press, 1985.

Levinas, Emmanuel. Éthique and infini: Dialogues avec Philippe Nemo. Paris: Fayard, 1982.

Levinas, Emmanuel. Otherwise than Being or Beyond Essence. Translated by Alphonso Lingis. Pittsburgh, PA: Duquesne University Press, 2011.

Morton, Stephen. States of Emergency: Colonialism, Literature and Law. Liverpool: Liverpool University Press, 2013.

Nakazawa, Keiji. Hadashi no Gen. [Barefoot Gen.] Vol. 1. Tokyo: Chōbun-sha, 1975a.

Nakazawa, Keiji. Hadashi no Gen. [Barefoot Gen.] Vol. 2. Tokyo: Chōbun-sha, 1975b.

Ranasinha, Ruvani. 'Resistance and Religion in the Work of Kamila Shamsie.' In Culture, Diaspora, and Modernity in Muslim Writing. Edited by Rehana Ahmed, Peter Morey and Amina Yaqin. Abingdon, England: Routledge, 2012. 200-214.

Ray, Gene. Terror and the Sublime in Art and Critical Theory: From Auschwitz to Hiroshima to September 11 and Beyond. London: Palgrave, 2005.

Shamsie, Kamila. Burnt Shadows. London: Bloomsbury, 2009.

Treat, John Whitter. Writing Ground Zero: Japanese Literature and the Atomic Bomb. Chicago, IL: University of Chicago Press, 1995. 